\title{
Study on the Cultural Self-Confidence of Socialism with Chinese Characteristics
}

\author{
Haicui Yang \\ The College of Economics and Administration, Tianjin University of Industry, Tianjin, China \\ Email: lycaipm@163.com
}

How to cite this paper: Yang, H.C. (2018) Study on the Cultural Self-Confidence of Socialism with Chinese Characteristics. Open Journal of Social Sciences, 6, 235-239. https://doi.org/10.4236/jss.2018.68019

Received: August 6, 2018

Accepted: August 21, 2018

Published: August 24, 2018

Copyright (C) 2018 by author and Scientific Research Publishing Inc. This work is licensed under the Creative Commons Attribution International License (CC BY 4.0).

http://creativecommons.org/licenses/by/4.0/

\begin{abstract}
This article takes the challenge of China's cultural self-confidence construction as the background, through the literature research, system research and other methods, discusses its important historical significance, and puts forward opinions and suggestions for the construction of cultural self-confidence in China.
\end{abstract}

\section{Keywords}

Culture, Cultural Self-Confidence, Socialism with Chinese Characteristics

\section{Overviews of the Cultural Self-Confidence of Socialism with Chinese Characteristics}

Cultural self-confidence is a country's inner soul, and also becoming the beliefs and support of the nation. Since the 18th CPC National Congress, Xi Jinping repeatedly referred to the building of cultural self-confidence, and in the new historical conditions, the Chinese culture of socialism self-confidence to be a special summary and interpretation, effectively put it in a prominent position. Chinese characteristics of socialist cultural self-confidence deeply rooted in the Chinese traditional culture, after the Communist Party led the people in the continuous cultural construction, creation, selection and beyond the process of development and growth; it is an important guarantee for the prosperity and development of the socialist culture and an important impetus for the development of China's economy and society.

Cultural self-confidence is a state of mind, which is based on the full affirmation of the country and the culture of the country, resulting in a sense of cultural honor and firm faith so as to produce a firm belief in the vitality of their own culture, with subjectivity, the times, class nature, inclusiveness, ethnicity and 
realistic orientation [1]. The cultural consciousness and self-confidence genes of Marxist classical writers on the theory of cultural self-confidence and Chinese excellent traditional culture, the ideological resources of Western Marxist representatives and contemporary scholars on cultural self-confidence, and the cultural self-confidence of Chinese Communists are the ideological resources and theoretical basis of cultural self-confidence with Chinese characteristics [2].

\section{The Theoretical Connotation of the Cultural Self-Confidence of Socialism with Chinese Characteristics}

The cultural self-confidence is primarily an ideological state and concerns the subject's full approval and firm belief of its own culture [3]. The cultural self-confidence covers the excellent Chinese traditional culture, the Chinese revolutionary culture and the contemporary socialism culture with Chinese characteristics. The remarkable achievements of China's economy, increasingly maturing social system, extensive and profound Chinese culture, and ever-growing international influence constitute the realistic foundation and conditional support for Chinese cultural self-confidence which are quite essential for any culture. Essentially speaking, based on the "Four confidence" of Chinese socialism path, system and theory, the cultural self-confidence of socialism with Chinese characteristics is the root and practical form of culture in contemporary China [4].

Even though there are different understandings towards the cultural confidence, the cultural self-confidence of socialism with Chinese characteristics is certainly the essence for cultural confidence from the spirits of 18th National Congress and the basic strategies of $19^{\text {th }}$ National Congress particularly which strengthens the cultural confidence and promotes the cultural prosperity. The cultural self-confidence is a whole on the theoretical, psychological and social value level, among which the last level takes a leading rank. From the dimension of subject and object relationship, who is confident, what to believe and how to realize the link between the subject and abject of cultural self-confidence are the structural relations to analyze. The cultural confidence has great strategic significance which involves the destiny of a nation.

\section{The Content Points of the Cultural Self-Confidence of Socialism with Chinese Characteristics}

We are considering and integrating the cultural resources and advantages. Cast in the revolutionary culture which highlights the leadership of the Communist Party of China and the advanced socialism culture, the socialism culture with Chinese characteristics originates from the excellent traditional Chinese culture that plays as its treasure house and historical foundation with rich contents and vitality from ancient times. It has theoretical confidence and advanced ideological connotation due to the guidance of Marxism and the supports from the great revolutionary spirit because it is intimately tied up with the Chinese revolutio- 
nary culture [5]. Meanwhile rooted in the practice of socialism with Chinese characteristics, the great achievements of the Chinese socialism grant the culture the basic contents and realistic energy. Apparently representing development direction of the advanced culture, the socialism Culture with Chinese characteristics adapts to the economic and social development in contemporary China and plays as the care of contemporary Chinese cultural self-confidence with historical advantages, scientific foundation, advanced ideological connotation and great spirit.

To firmly conceive the self-confidence in the socialist culture with Chinese characteristics, it is necessary to fully affirm the value of the brilliant traditional Chinese culture, firmly believe in the Marxist and Chinese Marxist faith, boldly absorb the advanced western culture for my use, and be adept at promoting the socialism with Chinese characteristics. Firmly established self-confidence in socialist culture with Chinese characteristics can help to realize the spiritual engine for the realization of cultural power and national rejuvenation. It will help to provide ideological guarantee for firm ruling self-confidence and stability of political power, and help to enhance the recognition of national mainstream cultural and realize the comprehensive development of the whole nation [6].

\section{The Problems to Solve during the Realization of the Socialism Cultural Self-Confidence with Chinese Characteristics}

Currently, in the practice of self-confidence socialist culture with Chinese characteristics, we have made great achievements, which is the result of notable success of the core value system construction and the cultivation of core value. The outstanding traditional culture has been the initially inherited and promoted; cultural industries and cultural undertakings flourish; foreign exchange of cultural field is fruitful. These achievements, due to adhering to the absolute leadership of the Chinese Communist Party on the cultural construction and reform, deepen the reform of cultural system, attach importance to the development of cultural industries, and focus on the rapid promotion of the regional cultural soft power of and cultural promotion [7].

Logically speaking, we have every reason to be confident of our existing culture, but in fact we are confronted with many challenges to realize the socialism cultural self-confidence with Chinese characteristics such as the urgent new problem of how to deepen the cultural self-confidence by practice to truly help the great rejuvenation of the Chinese nation. For one thing, a greater cultural voice in the international society for contemporary China is urgently needed compared with the universally well-known achievements in economic and social developments. And in the aspect of soft power, the objective lack of confidence for Chinese includes the cognitive deficit for excellent traditional Chinese culture, the blind worship to western culture and less influence and appeal of the socialism ideology with Chinese characteristics. The lack of discourse power becomes a pressing task for the socialism cultural self-confidence with Chinese 
characteristics to deal with. And the main causes include the weak cultural self-awareness of the contemporary Chinese, the impact and penetration of powerful western culture, further improvement for guiding force of Chinese dominating culture and the constrains of conflicts from socialism practice.

\section{The Path to Carry Out the Cultural Self-Confidence of Socialism with Chinese Characteristics}

To fulfill the cultural self-confidence of socialism with Chinese characteristics is not only an ideological theory but a practice to reinforce the cultural construction by practical wisdom. The socialism culture with Chinese characteristics is undoubtedly promising and energetic and has every reason for the Chinese to be hopeful towards its future. We need to enhance and foster it from the following aspects: from the dimension of cultural subjects, the self-confidence awareness should be improved; from the dimension of cultural comparison, the advantages of our native culture need to be stressed to make the people confident about their culture's value and vitality and the problem of believing in others also needs to be emphasized and realized in the intercultural dialogues; from the dimension of creativity, only the ceaseless innovations on the basis of inheritance can provide cultural self-confidence with powerful guarantee to reach selfsupport; from the concrete approaches to achieve it, it is helpful to construct Chinese discourse system and transmit the Chinese values when our culture stands in an inferior position so that the Chinese influence can be enhanced by the implement of "go-global" strategy. The cultural self-confidence of socialism with Chinese characteristics is not only a spiritual demand, but needs more attention to construction [8].

In view of the existing problems and reasons that restrict the self-confidence in socialist culture with Chinese characteristics, we should focus on improving and optimizing the practice of self-confidence in socialist culture with Chinese characteristics from the perspective of subject, object, content and standards [9]. First, from the perspective of subject, we earnestly carry out core values and education on traditional culture should be earnestly carried out, so as to enhance the awareness of national culture self-confidence. Second, from the point of object, we should adhere to the reform of the cultural system to enhance the soft strength, and consolidate the basis of cultural self-confidence. Third, to the content level, cultural achievements should continue to innovated and bad tendencies should be criticized, so that the protection of cultural self-confidence will be solidly laid. Fourth, to the standard level, we should speed up the development of evaluation index system of cultural self-confidence, and improve the principle requirements of cultural self-confidence [10].

In the realization of the journey of the great rejuvenation of the Chinese nation, we should firmly believe in cultural self-confidence. Firmly believing in cultural self-confidence, achieving cultural self-improvement, and building a cultural power to match China's economic development, enhancing the overall strength, influence and competitiveness of Chinese culture, and consolidating 
the national spirit, are Chinese nation's spiritual engine and culture guarantee of realizing the great rejuvenation of the Chinese nation.

\section{Conflicts of Interest}

The authors declare no conflicts of interest regarding the publication of this paper.

\section{References}

[1] Cheng, S.G. and Yang, J. (2016) A Discussion on Cultural Self-Confidence. Study on Cultural Soft Power, 3.

[2] Zhang, H.D. (2018) Three Basic Dimensions of Strengthening Cultural Self-Confidence. Academic Exploration, 4.

[3] Marx, K. and Engels, F. (1995) Marx and Engel's Selected Works. Volume 1, People's Publishing House, Beijing, 42.

[4] Guo, J.N. (2018) Cultural Self-Confidence and Contemporary China. Journal of Peking University (Philosophy and Social Sciences), 3.

[5] An, X.J. (2016) Three Dimensions of Cultural Confidence. People's Tribune, 5.

[6] Geng, C. (2016) On the Confidence of Socialist Culture with Chinese Characteristics. Guangxi Normal University Press, Guilin, 121.

[7] Chen, X.D. (2016) Cultural Confidence and the Great Rejuvenation of the Chinese Nation. People's Publishing House, Beijing, 85.

[8] Feng, T.Y. (2006) Research on the Construction of Socialist Culture with Chinese Characteristics. Wuhan University Press, Wuhan, 27.

[9] Hu, G.Y. (2011) Cultural Construction of the Communist Party of China. People's Publishing House, Beijing, 78.

[10] Lu, Y. (2013) The Introduction of Cultural Studies. Fudan University Press, Shanghai, 43 . 